Bangladesh J. Sci. Ind. Res. 43(1), 1-12, 2008

\title{
Nutrient Content of Poultry Feed Used in Different Poultry Farms of Bangladesh
}

\author{
M.M.H. Khan ${ }^{\mathrm{a}}$, B. Chowdhury ${ }^{\mathrm{b}}$, M.R.H. Bhuiyan ${ }^{\mathrm{b}}$, M.J. Uddin ${ }^{\mathrm{a}}$, \\ M. Dawlatana ${ }^{\mathrm{c}}$ and M. Rahim ${ }^{\mathrm{c}}$ \\ ${ }^{a}$ Sylhet Govt. Veterinary College, Sylhet, ${ }^{b}$ Dept. of Biochemistry, BAU, Mymensingh and \\ 'IFST, Bangladesh Council of Scientific and Industrial Research, Dhaka, Bangladesh
}

\begin{abstract}
As quality of feed is the main determinant factor in successful poultry farming attempts were made to evaluate the quality of feeds used in the farms of Bangladesh. Feed samples were collected from two layer farm, four big hatcheries and six broiler farms located in different areas of Bangladesh and the collection was continued for twelve months. For monitoring the quality, dry matter, crude protein, ether extract, ash and calcium content in the feed were determined. The information regarding the source and ingredients of the feed as well as the feeding practices followed by the farms was also recorded. Based on age, purpose and stage of production, different feeding systems were practiced by the farms. In the present investigation, breeder farms were found to own feed-mill where they produced their feed and the quality of the feed appeared better compared to those used in broiler or layer farms. The nutrient contents in breeder ration were as per recommendation of the strain producing company. A wide variation of nutrient contents was observed in the feed fed to broilers in different farms. When the broiler feed was produced in the own feed-mill of the farm or supplied from a renowned feed- mill, the quality appeared to be quite acceptable with some deviation. Some self-prepared broiler feeds contained higher amount of ash and calcium. The broiler feed from retailer shop was found to be least acceptable. Remarkable fluctuation was noticed in metabolizable energy( $\mathrm{ME}$ ) and ash content of layer layer feed procured from the retailer shop.
\end{abstract}

Key words : Poultry feed, Nutrient content, Breeder feed, Broiler feed, Layer feed

\section{Introduction}

Poultry production is an important part of animal agriculture. By increasing the pro- ductivity of poultry meat and eggs, the existing gap between supply and demand of ani- 
mal protein can be bridged. Poultry meat contributes around $37 \%$ of the total animal protein supply of Bangladesh (Ahmed and Islam, 1990). Poultry meat and eggs are quality food in respect amino acid ingredients and therefore, can improve considerably an otherwise unbalanced diet. It also provides cash income and creates employment opportunity for small and landless farmers.

Though presently only 15\% of the total poultry products are coming from commercial farms, poultry industry has established its position as the fastest growing segment in the agricultural sector. Bangladesh Government has also come forward for the improvement of this sector and offering training and financial assistance to marginal entrepreneurs. Profitable poultry farming is a highly specialized job in which a lot of factors may be responsible to offset the profit amount. Among these, quality of chicks and feeds are most important. Feed alone accounts for approximately $65-70 \%$ of the total cost of production of poultry meat and eggs. As nutrition is one of the most important factors for successful poultry farming, a booming poultry feed business is appearing all over the country. Different feed ingredients are being important to prepare low cost but nutritionally balanced poultry ration.

A number of feed mills are producing poultry feed, which is purchased by farm-owners according to their need. Farmers do not have enough facility to analyze and monitor the quality of the feed. Often they formulate the ration for their own birds from ingredients on the basis of the information about the feed components mentioned elsewhere. In view of the availability and source of different feed ingredients, the level of nutrients in the prepared ration may vary from what is actually desired. Deficiency of a particular nutrient in the ration may not be over-ruled which is generally unnoticed by the farm-owners causing a devastating effect on production. To get an exact picture of the feeding practices as well as to asses the quality of the poultry feeds being used in farms located in different areas of Bangladesh, round the year, biochemical analysis (nutritional quality) of the feed seems to be worthwhile. The present study was therefore, undertaken to observe the source of feed and feeding practices followed by the farm and to assess the nutritive value of feeds collected from the poultry farms, round the year.

\section{Materials and Methods}

\section{Experimental work plan}

Feed samples were collected from different poultry farms. Proximate analysis and Aflatoxin analysis of feed samples was performed in the Biochemistry Laboratory, Department of Biochemistry and Food Toxicology research section, IFST, BCSIR, Dhaka. Calcium contents of feed sample was determined in Agri-chemistry Laboratory, Department of Agricultural Chemistry at 
Bangladesh Agricultural University (BAU), Mymensingh.

\section{Sample collection}

Feed samples were collected from twelve different poultry farms located in different areas of Bangladesh. Four of them are situated at Mymensingh; five at Gazipur; two at Dhaka and one was selected from those at Chittagong. Among them two were layer farms, four were big hatcheries and the rest were broiler-farms. At the commencement of
Along with the feed sample the supplied information sheet duly filled in for each respective sample, was also collected.

\section{Procedure of composite sampling}

In case of big farms, ten bags were selected randomly. From each bag about $0.5 \mathrm{~kg}$ of feed sample was pooled together so that total amount became $5 \mathrm{~kg}$. They were mixed thoroughly and about $2 \mathrm{~kg}$ of sample was collected from that mixed feed. In case of small farms composite sampling was made from

Table. I. Precise information about the poultry farms under investigation.

\begin{tabular}{c|l|l|r|c}
\hline Farm No & Location & Type of farm & No.of birds & Source of feed \\
\hline 1. & Mymensingh & Broiler & 500 & RF \\
2. & Mymensingh & Broiler & 1000 & RF / SP \\
3. & Mymensingh & Layer & 500 & RF \\
4. & Mymensingh & Breeder & 10,000 & RF \\
5. & Gazipur & Breeder & $10,00,000$ & SP \\
6. & Chittagong & Broiler & 1000 & RF \\
7. & Gazipur & Broiler & 5000 & RF \\
8. & Gazipur & Breeder & 10,000 & RF \\
9. & Dhaka & Layer & 1000 & RS \\
10. & Dhaka & Broiler & 800 & RS \\
11. & Gazipur & Breeder & 100,000 & SP \\
12. & Gazipur & Broiler & 2,000 & RF \\
\hline
\end{tabular}

$\mathrm{RF}=$ Renowned feed-mill, $\quad \mathrm{SP}=$ Self produced,

investigation, an "Information sheet" was given to each farm. Feed samples were collected twice a month at an interval of fifteen days between each successive collection. Feed collection was begun from December 2000 and continued till November 2001. only 2-3 bags of feed sample. The deviation was accepted because the small farms generally procure or prepare less amount of feed at a time.

A code number was given to each collected sample following the rules mentioned below. 
The first numerical digit attached to "F" represents the serial number of the farm and the second, the sample number.

The feed samples were ground by using micro grinder (A-10 Analytical mill. Tekmar. Germany) and was passed through 100 mesh sieve.

\section{Determination of nutrient contents of feed sample}

The procedures for the estimation of dry matter, crude protein(CP), ether extract (EE) and ash were those of AOAC. The total sugar was determined according to the method of Hall and Haczkaylo. The starch analysis was performed according to the method of Kent- Jones and Amos . The calcium and phosphorus content of the feed sample were determined according to the method of Page et al, (1982). The ME content of the feed samples was determined indirectly by using the values of $\mathrm{CP}, \mathrm{EE}$, Su and St fitted to a formula suggested by Leclercq et al, (1987).

\section{Determination of Aflatoxin from Feed Sample}

Aflatoxin was determined in toxicology laboratory of the Institute of Food Science and Technology (IFST), Bangladesh Council of Scientific and Industrial Research (BCSIR), Dhaka.Extraction was done according to method of Romer. Aflatoxin was quantitated according to the method of Coker et al,
(1988). Coefficient of variance was determined according to Shil and Debnath, (2001).

\section{Results and Discussion}

Variation of nutrient contents in poultry feed used in different farms: Analytical data of the feed samples collected from different poultry farms, round the year, are given successively in respective tables. Farm owners occasionally declined to supply feed samples for analysis, so the analytical data of those feeds are not shown in the tables.

The information regarding the level of different nutrients in the feed as mentioned by the feed-miller or assumed by the individual farm when the ration was formulated by themselves are also included in the tables. It was done in order to compare the actual nutrient content of the feed with that of the mentioned/assumed values. The total sugar and starch contents of the feed samples were determined to calculate the metabolizable energy (ME) contained in the feed. The concept of ME: CP is very useful in poultry feeding so that, it is also included in each table.

From nutritional point of view different poultry farm used different types of feeding system based on age, purpose and stage of production. Breeder farms such as F04, F05, F08 and F11 had followed the same type of feeding system for breeder birds. They used starter, grower, pre-breeder, breeder-I and 
Table II. Nutritional composition of the poultry feed samples (broiler starter) collected from different farms

\begin{tabular}{|c|c|c|c|c|c|c|c|c|}
\hline $\begin{array}{l}\text { Farm no. } \\
\text { and Number } \\
\text { of sample }\end{array}$ & & DM & $\mathrm{CP}$ & $\mathrm{EE}$ & Ash & $\mathrm{Ca}$ & $\mathrm{ME}$ & $\mathrm{ME}: \mathrm{CP}$ \\
\hline F- 01 & Avr. & $88.05 \pm 1.35$ & $21.17 \pm 0.12$ & $9.31 \pm 0.21$ & $6.85 \pm 0.30$ & $1.02 \pm 0.05$ & $3084 \pm 23.36$ & $146 \pm 0.69$ \\
\hline S - 05 & $\mathrm{CV}$ & 1.54 & 0.56 & 2.21 & 4.33 & 5.11 & 0.76 & 0.47 \\
\hline F - 02 & Avr. & $88.43 \pm 1.30$ & $21.00 \pm 0.33$ & $10.10 \pm 0.19$ & $6.66 \pm 0.42$ & $0.94 \pm 0.03$ & $3107 \pm 49.30$ & $148 \pm 5.60$ \\
\hline$S-05$ & $\mathrm{CV}$ & 1.47 & 1.57 & 1.88 & 6.30 & 2.75 & 1.59 & 1.34 \\
\hline F - 04 & Avr. & $89.08 \pm 0.79$ & $21.45 \pm 0.68$ & $7.52 \pm 0.28$ & $7.66 \pm 0.87$ & $1.07 \pm 0.14$ & $2997 \pm 55.12$ & $140 \pm 4.38$ \\
\hline$S-04$ & $\mathrm{CV}$ & 0.89 & 3.19 & 3.77 & 11.31 & 13.02 & 1.84 & 3.18 \\
\hline$F-05$ & Avr. & $88.01 \pm 1.29$ & $21.08 \pm 0.38$ & $6.81 \pm 0.28$ & $6.40 \pm 0.31$ & $0.99 \pm 0.08$ & $2903 \pm 63.44$ & $138 \pm 5.53$ \\
\hline S - 03 & $\mathrm{CV}$ & 1.47 & 1.82 & 4.15 & 4.84 & 7.63 & 2.19 & 3.98 \\
\hline$F-06$ & Avr. & $88.63 \pm 0.49$ & $22.12 \pm 0.18$ & $6.29 \pm 0.25$ & $5.22 \pm 0.09$ & $0.91 \pm 0.04$ & $2910 \pm 19.77$ & $132 \pm 1.55$ \\
\hline S - 04 & $\mathrm{CV}$ & 0.55 & 0.80 & 4.04 & 1.64 & 4.58 & 0.68 & 1.18 \\
\hline$F-07$ & Avr. & $88.63 \pm 0.81$ & $21.15 \pm 1.14$ & $9.04 \pm 0.64$ & $9.23 \pm 1.63$ & $1.37 \pm 0.47$ & $2975 \pm 55.47$ & $141 \pm 7.25$ \\
\hline S - 06 & $\mathrm{CV}$ & 0.91 & 5.41 & 7.05 & 17.61 & 34.55 & 1.86 & 5.14 \\
\hline$F-08$ & Avr. & $88.83 \pm 0.93$ & $21.58 \pm 0.32$ & $7.53 \pm 0.24$ & $8.98 \pm 0.54$ & $1.09 \pm 0.09$ & $3042 \pm 58.27$ & $141 \pm 3.20$ \\
\hline S - 06 & $\mathrm{CV}$ & 1.05 & 1.49 & 3.22 & 6.01 & 7.88 & 1.92 & 1.89 \\
\hline$F-10$ & Avr. & $86.55 \pm 1.89$ & $19.25 \pm 1.37$ & $6.70 \pm 0.86$ & $11.99 \pm 1.51$ & $1.29 \pm 0.65$ & $2881 \pm 142.35$ & $150 \pm 7.65$ \\
\hline S - 05 & $\mathrm{CV}$ & 2.18 & 7.14 & 12.89 & 12.57 & 50.53 & 4.94 & 5.10 \\
\hline$F-11$ & Avr. & $88.47 \pm 0.59$ & $22.19 \pm 0.42$ & $6.20 \pm 0.98$ & $6.56 \pm 1.89$ & $1.01 \pm 0.10$ & $3013 \pm 56.66$ & $136 \pm 4.86$ \\
\hline S - 08 & $\mathrm{CV}$ & 0.66 & 1.87 & 15.84 & 28.77 & 9.41 & 1.88 & 3.58 \\
\hline F-12 & Avr. & $89.90 \pm 1.15$ & $21.82 \pm 0.98$ & $7.12 \pm 2.14$ & $6.17 \pm 1.17$ & $0.95 \pm 0.07$ & $3006 \pm 87.37$ & $138 \pm 8.59$ \\
\hline$S-10$ & $\mathrm{CV}$ & 1.28 & 3.40 & 30.01 & 19.03 & 7.00 & 2.91 & 6.23 \\
\hline \multicolumn{2}{|c|}{ Desired level } & $88.00-90.00$ & $21.5-22.0$ & & & 1.00 & $2950-3100$ & $135-140$ \\
\hline
\end{tabular}

breeder-II feed successively. In case of broiler feeding, variation in feeding practice was found among the farms. Farms F01, F02 and F12 used broiler starter, broiler grower and broiler finisher ration. On the other hand, farms F04, F05, F06, F07, F08 and F10 had omitted the ration for broiler grower stage and they switched over directly from broiler starter feed to broiler finisher feed.
It was noticed that farm-11 followed a rather modified feeding practice in case of broiler. As it appeared from the table II that five different types of feeds such as broiler starter-I, broiler starter-II, broiler grower, broiler finisher and broiler withdrawal were used. Broiler starter-I was fed from day-old to 7days-old birds. From 8 days to 14 days broiler starter-II was used. Both were similar in 
Table III. Nutritional composition of the poultry feed samples (broiler grower) collected from different farms

\begin{tabular}{l|c|r|r|r|r|r|r|r}
\hline $\begin{array}{l}\text { Farm no. } \\
\text { and Number } \\
\text { of sample }\end{array}$ & & DM & CP & EE & Ash & Ca & ME & ME:CP \\
\hline F - 01 & Avr. & $89.25 \pm 0.87$ & $20.01 \pm 0.60$ & $8.97 \pm 0.72$ & $6.38 \pm 0.38$ & $1.08 \pm 0.08$ & $2982 \pm 130.8$ & $149 \pm 5.60$ \\
S - 05 & CV & 0.98 & 2.99 & 7.98 & 5.93 & 7.20 & 4.39 & 3.76 \\
\hline F - 02 & Avr. & $88.36 \pm 1.41$ & $19.66 \pm 0.74$ & $8.41 \pm 1.13$ & $6.84 \pm 1.17$ & $1.12 \pm 0.10$ & $3133 \pm 16.97$ & $157 \pm 4.70$ \\
S - 06 & CV & 1.59 & 3.74 & 13.49 & 17.07 & 8.70 & 0.54 & 2.99 \\
\hline F-11 & Avr. & $88.68 \pm 2.01$ & $21.73 \pm 0.32$ & $7.90 \pm 0.31$ & $6.56 \pm 0.22$ & $1.04 \pm 0.02$ & $3062 \pm 25.71$ & $136 \pm 4.87$ \\
S - 03 & CV & 2.26 & 1.45 & 3.92 & 3.35 & 1.67 & 0.84 & 3.58 \\
\hline F - 12 & Avr. & $89.03 \pm 1.53$ & $21.37 \pm 0.03$ & $8.02 \pm 0.18$ & $6.53 \pm 0.19$ & $1.01 \pm 0.02$ & $3094 \pm 13.08$ & $144 \pm 0.70$ \\
S-03 & CV & 1.72 & 0.14 & 2.22 & 2.92 & 2.29 & 0.42 & 0.49 \\
\hline F01-12 & Avr. & 87.83 & 19.63 & 8.37 & 6.12 & 1.18 & 2858 & $146: 1$ \\
\hline F02-17 & Avr. & 87.54 & 19.62 & 8.14 & 10.26 & 1.35 & 3121 & $162: 1$ \\
\hline F07-03 & Avr. & 89.32 & 8.96 & 9.46 & 10.70 & 2.06 & 2928 & $154: 1$ \\
\hline F07-05 & Avr. & 88.23 & 20.85 & 9.86 & 11.01 & 1.87 & 2990 & $143: 1$ \\
\hline F07-1 & Avr. & 88.78 & 19.58 & 9.86 & 12.34 & 2.58 & 2747 & $140: 1$ \\
\hline F07-4 & Avr. & 88.54 & 20.22 & 8.98 & 11.75 & 2.26 & 2548 & $126: 1$ \\
\hline F07-07 & Avr. & 89.64 & 20.30 & 9.15 & 12.49 & 2.34 & 2581 & $127: 1$ \\
\hline F07-10 & Avr. & 88.59 & 20.66 & 9.39 & 12.94 & 2.14 & 2627 & $127: 1$ \\
\hline Desired level & & $88-90$ & $20.0-21-5$ & & & 1.00 & $3000-3125$ & $150-155$ \\
\hline
\end{tabular}

nutrient contents but different in particle size. From 15 days to 21 days broiler grower feed was used which had slightly lower CP\% (19.25) and higher ME (2881) than that of broiler starter. From 22 days to 28 days broiler finisher ration was fed which contained more ME and less CP than did broiler grower ration. From 29 days till marketing broiler-withdrawal feed was continued. The only difference between broiler finisher and broiler-withdrawal was that the broiler-withdrawal was devoid of coccidiostat.
Broiler feed samples were collected from F01, F02, F04, F05, F06, F07, F08, F10, F11 and F12. As farm F08 and F11 were breeder farm and had laboratory facility for feed analysis, different nutrient contents in their feed were amazingly uniform and perfectly adhered to the range as chosen by the ration formulator. The quality of broiler feeds from farm F05 was quite acceptable with respect to their nutrient contents. Farm F01, F02, F04, F06 and F12 had procured their feed from renowned feed-mill and the quality was considered good with some reservation. The 
feed sample F01-12 contained relatively lower amount of CP (19.63\%) and ME (2858 $\mathrm{kcal} / \mathrm{kg}$ ). Farm F02 also produced its feed for the month of December 2000 and for the period from July to November 2001. The self-prepared feed F02-17 contained higher amount of ash (10.26\%) and Ca (1.35\%).

The broiler feed from farm F07 and F10 appeared to be least acceptable. The broiler starter feed samples F07-03 and F07-05 contained extremely high amount of ash, and Ca. The CP\% of these two samples (18.96\% and $20.85 \%$ ) was lower than the desired level (21.50\%). The broiler finisher feed collected from December 2000 to March 2001 (F07-01, F07-04, F07-07 and F07-10) also contained alarmingly high amount of ash (11.75 to $12.94 \%$ ) and Ca (2.14 to $2.58 \%$ ).

Table IV. Nutritional composition of the poultry feed samples (broiler finisher) collected from different farms

\begin{tabular}{|c|c|c|c|c|c|c|c|c|}
\hline $\begin{array}{l}\text { Farm no. } \\
\text { and Number } \\
\text { of sample }\end{array}$ & & DM & $\mathrm{CP}$ & $\mathrm{EE}$ & Ash & $\mathrm{Ca}$ & $\mathrm{ME}$ & ME:CP \\
\hline$F-1$ & Avr. & $88.36 \pm 1.41$ & $19.66 \pm 0.74$ & $8.41 \pm 1.13$ & $6.84 \pm 1.17$ & $1.12 \pm 0.10$ & $3133 \pm 16.97$ & $160 \pm 5.72$ \\
\hline$S-8$ & $\mathrm{CV}$ & 1.59 & 3.74 & 13.49 & 17.07 & 8.70 & 0.54 & 3.58 \\
\hline$F-2$ & Avr. & $88.43 \pm 0.88$ & $19.93 \pm 0.53$ & $8.60 \pm 0.92$ & $9.78 \pm 0.48$ & $1.24 \pm 0.92$ & $3161 \pm 38.39$ & $159 \pm 4.62$ \\
\hline$S-7$ & $\mathrm{CV}$ & 0.99 & 2.66 & 10.64 & 4.86 & 11.18 & 1.21 & 2.90 \\
\hline$F-4$ & Avr. & $89.04 \pm 0.86$ & $20.64 \pm 0.43$ & $9.37 \pm 0.28$ & $8.37 \pm 0.46$ & $1.00 \pm 0.09$ & $3017 \pm 11.65$ & $155 \pm 3.60$ \\
\hline$S-10$ & $\mathrm{CV}$ & 0.96 & 2.07 & 3.00 & 5.54 & 9.06 & 0.39 & 2.32 \\
\hline$F-5$ & Avr. & $88.63 \pm 0.61$ & $20.11 \pm 0.19$ & $9.52 \pm 0.19$ & $6.93 \pm 0.25$ & $1.10 \pm 0.09$ & $3168 \pm 13.95$ & $157 \pm 1.48$ \\
\hline S - 7 & $\mathrm{CV}$ & 0.69 & 0.94 & 1.99 & 3.56 & 7.74 & 0.44 & 0.94 \\
\hline F -6 & Avr. & $88.91 \pm 1.06$ & $19.97 \pm 0.37$ & $8.38 \pm 0.61$ & $6.55 \pm 0.30$ & $1.11 \pm 0.08$ & $3097 \pm 34.40$ & $154 \pm 3.52$ \\
\hline$S-16$ & $\mathrm{CV}$ & 1.20 & 1.85 & 7.29 & 4.57 & 7.43 & 1.11 & 2.29 \\
\hline F - 7 & Avr. & $88.32 \pm 1.24$ & $20.31 \pm 0.38$ & $9.56 \pm 0.47$ & $10.99 \pm 1.51$ & $1.71 \pm 0.61$ & $2848 \pm 219.42$ & $140 \pm 10.83$ \\
\hline$S-9$ & $\mathrm{CV}$ & 1.41 & 1.87 & 4.89 & 13.72 & 35.58 & 7.70 & 7.73 \\
\hline$F-8$ & Avr. & $88.80 \pm 0.97$ & $20.67 \pm 0.34$ & $9.73 \pm 0.49$ & $8.24 \pm 1.16$ & $1.05 \pm 0.07$ & $3128 \pm 37.89$ & $149 \pm 3.12$ \\
\hline$S-10$ & $\mathrm{CV}$ & 1.09 & 1.64 & 5.02 & 14.10 & 6.66 & 1.21 & 2.09 \\
\hline F - 103 & Avr. & $86.72 \pm 2.91$ & $19.16 \pm 1.34$ & $5.63 \pm 1.15$ & $11.66 \pm 1.27$ & $1.15 \pm 0.51$ & $2749 \pm 201.82$ & $143 \pm 7.82$ \\
\hline$S-1$ & $\mathrm{CV}$ & 3.35 & 7.01 & 20.41 & 10.90 & 43.98 & 7.34 & 5.47 \\
\hline $\mathrm{F}-11$ & Avr. & $88.47 \pm 0.59$ & $22.19 \pm 0.42$ & $6.20 \pm 0.98$ & $6.56 \pm 1.89$ & $1.01 \pm 0.10$ & $3013 \pm 56.66$ & $136 \pm 4.87$ \\
\hline$S-8$ & $\mathrm{CV}$ & 0.66 & 1.87 & 15.84 & 28.77 & 9.41 & 1.88 & 3.58 \\
\hline $\mathrm{F}-12$ & Avr. & $89.64 \pm 1.43$ & $21.20 \pm 0.63$ & $8.67 \pm 0.93$ & $7.42 \pm 1.56$ & $1.00 \pm 0.09$ & $3045 \pm 166.34$ & \\
\hline$S-8$ & $\mathrm{CV}$ & 1.60 & 2.96 & 10.74 & 21.07 & 9.10 & 5.46 & \\
\hline \multicolumn{2}{|c|}{ Desired level } & $88-90$ & $19.0-20.0$ & & & 1.00 & $3100-3200$ & $160-170$ \\
\hline
\end{tabular}


The average ME (2848 kcal/kg) as well as ME: CP ratio (140:1) of the broiler finisher feed was much lower than those of desired values (3000-3100 kcal/kg and 150- 155). The farm F10 procured their feed from retailer shop. A wide variation of different nutrient contents was observed in broiler starter as well as in broiler finisher feed. The $\mathrm{CP} \%$ of broiler starter feed varied from 17.74 to $20.79 \%$. The ME value of the feed varied from 2718 to $3044 \mathrm{kcal} / \mathrm{kg}$ with an average value of $2881 \mathrm{kcal} / \mathrm{kg}$ which was few cases, sudden fall was observed in ash (9.52 and 9.53\%) and in Ca (0.61, 0.68 and $0.69 \%$ ) content of the feed. In most of the cases, the ME was alarmingly low (ranged from 2315 to $3086 \mathrm{kcal} / \mathrm{kg}$ feed) compared to the recommended level (3100 kcal/kg).

In case of layer birds, farm F08 used starter feed, grower feed, pre-layer feed and layer layer feed. On the other hand, farm F03 had omitted the pre-layer stage of feeding. Farm F09 used only starter and layer layer feed.

Table V. Nutritional composition of the poultry feed samples (layer starter and layer grower) collected from different farms

\begin{tabular}{|c|c|c|c|c|c|c|c|c|}
\hline $\begin{array}{l}\text { Farm no. } \\
\text { and Number } \\
\text { of sample }\end{array}$ & & $\mathrm{DM}$ & $\mathrm{CP}$ & $\mathrm{EE}$ & Ash & $\mathrm{Ca}$ & $\mathrm{ME}$ & ME:CP \\
\hline F- 3 & Avr. & $87.07 \pm 0.73$ & $19.04 \pm 0.17$ & $5.02 \pm 0.18$ & $7.04 \pm 0.18$ & $1.14 \pm 0.08$ & $2481 \pm 37.17$ & $130 \pm 2.21$ \\
\hline$S-3$ & $\mathrm{CV}$ & 0.84 & 0.89 & 3.59 & 2.57 & 7.09 & 1.50 & 1.70 \\
\hline F - 5 & Avr. & $88.97 \pm 0.86$ & $20.36 \pm 0.30$ & $6.95 \pm 0.22$ & $6.44 \pm 0.16$ & $1.18 \pm 0.08$ & $2822 \pm 43.13$ & $139 \pm 4.19$ \\
\hline S - 2 & $\mathrm{CV}$ & 0.97 & 1.49 & 3.15 & 2.53 & 7.19 & 1.53 & 3.02 \\
\hline F- 9 & Avr. & $88.49 \pm 0.34$ & $19.91 \pm 0.50$ & $4.18 \pm 0.14$ & $7.19 \pm 0.04$ & $1.58 \pm 0.60$ & $2699 \pm 177.48$ & $136 \pm 5.50$ \\
\hline S - 2 & $\mathrm{CV}$ & 0.38 & 2.52 & 3.38 & 0.49 & 38.04 & 6.58 & 4.04 \\
\hline Desired level & & 88- 90 & $19.0-19.5$ & & & 1.00 & $2750-2850$ & 135-140:1 \\
\hline \multicolumn{9}{|c|}{ Layer Grower } \\
\hline$F-3$ & Avr. & $88.87 \pm 0.75$ & $18.74 \pm 0.17$ & $5.98 \pm 0.70$ & $10.91 \pm 0.40$ & $2.24 \pm 0.08$ & $2658 \pm 53.47$ & $142 \pm 3.57$ \\
\hline S - 6 & $\mathrm{CV}$ & 0.84 & 0.90 & 11.67 & 3.66 & 3.61 & 2.01 & 2.51 \\
\hline \multicolumn{2}{|c|}{ Desired level } & $88-90$ & $16.5-17.5$ & & & 1.00 & $2650-2750$ & $150: 1$ \\
\hline
\end{tabular}

much lower than the recommended value of $3000 \mathrm{kcal} / \mathrm{kg}$. In case of broiler finisher ration the CP\% varied from 16.46 to $21.80 \%$ with an average value of $19.16 \%$, which was lower than the recommended value (20\%). In
The feed samples for layer were collected from F03, F05 and F09. The layer starter feed of farm F03 was found quite deficient in ME (Avr-2481 kcal/kg) compared to recom 
Table VI. Nutritional composition of the poultry feed samples (layer finisher) collected from different farms

\begin{tabular}{l|c|r|r|r|r|r|r|r}
\hline $\begin{array}{l}\text { Farm no. } \\
\text { and Number } \\
\text { of sample }\end{array}$ & & DM & CP & EE & Ash & Ca & ME & ME:CP \\
\hline F - 3 & Avr. & $87.03 \pm 1.25$ & $17.98 \pm 0.25$ & $6.20 \pm 0.37$ & $13.12 \pm 1.10$ & $3.46 \pm 0.32$ & $2896 \pm 187.55$ & $161 \pm 2.40$ \\
S - 10 & CV & 1.43 & 1.40 & 6.01 & 8.38 & 9.34 & 6.48 & 1.49 \\
\hline F - 5 & Avr. & $89.72 \pm 0.62$ & $17.91 \pm 0.75$ & $9.55 \pm 0.31$ & $16.26 \pm 3.58$ & $4.59 \pm 1.26$ & $2809 \pm 63.29$ & $157 \pm 6.32$ \\
S - 6 & CV & 0.69 & 4.20 & 3.27 & 22.01 & 27.49 & 2.25 & 4.03 \\
\hline F - 9 & Avr. & $89.30 \pm 0.64$ & $18.44 \pm 0.48$ & $4.50 \pm 1.17$ & $11.12 \pm 1.80$ & $3.52 \pm 0.43$ & $2706 \pm 123.17$ & $147 \pm 7.12$ \\
S - 16 & CV & 0.71 & 2.62 & 26.01 & 16.22 & 12.08 & 4.55 & 4.84 \\
\hline Desired level & & $88-90$ & $17.5-18.0$ & & & $3.50-3.75$ & $2800-2900$ & $160-165: 1$ \\
\hline
\end{tabular}

Table VII. Nutritional composition of the poultry feed samples (breeder ration) collected from different farms

\begin{tabular}{|c|c|c|c|c|c|c|c|c|}
\hline $\begin{array}{l}\text { Farm no. } \\
\text { and Number } \\
\text { of sample }\end{array}$ & & DM & CP & $\mathrm{EE}$ & Ash & $\mathrm{Ca}$ & $\mathrm{ME}$ & ME:CP \\
\hline \multicolumn{9}{|c|}{ Breeder starter } \\
\hline$F-4, S-1$ & & 89.86 & 21.63 & 7.55 & 13.24 & 2.53 & 2919 & $135: 1$ \\
\hline $\mathrm{F}-11, \mathrm{~S}-1$ & & 89.05 & 21.62 & 5.10 & 6.60 & 1.02 & 2967 & 137: 1 \\
\hline Desired level & & $89-90$ & 21.5 & & & 1.00 & 2900 & $135: 1$ \\
\hline \multicolumn{9}{|c|}{ Breeder grower } \\
\hline F- 11 & Avr. & $87.88 \pm 0.29$ & $16.58 \pm 0.41$ & $3.58 \pm 0.04$ & 6.94 & $0.96 \pm 0.04$ & $2785 \pm 5.66$ & $168 \pm 3.81$ \\
\hline$S-2$ & $\mathrm{CV}$ & 0.33 & 2.47 & 0.99 & 0.00 & 3.68 & 0.20 & 2.27 \\
\hline Desired level & & $88-90$ & $16.0-16.5$ & & & 0.95 & $2750-2800$ & 165-170:1 \\
\hline \multicolumn{9}{|c|}{ Breeder finisher } \\
\hline$F-4, S-1$ & & 89.44 & 18.52 & 9.94 & 15.62 & 4.23 & 3029.4 & 160:1 \\
\hline F- 8 & Avr. & $88.61 \pm 0.31$ & $17.60 \pm 0.16$ & $7.00 \pm 1.10$ & $12.62 \pm 0.08$ & $3.64 \pm 3.54$ & $2981 \pm 0.15$ & $169 \pm 3.20$ \\
\hline$S-2$ & $\mathrm{CV}$ & 0.35 & 0.92 & 15.66 & 0.62 & 97.13 & 0 & 1.89 \\
\hline$F-11$ & Avr. & $88.68 \pm 0.05$ & $17.17 \pm 0.40$ & $7.50 \pm 0.74$ & $13.54 \pm 0.01$ & $3.63 \pm 0.09$ & $2900 \pm 31.11$ & $164 \pm 5.42$ \\
\hline S - 2 & $\mathrm{CV}$ & 0.06 & 2.31 & 9.90 & 0.05 & 2.53 & 1.07 & 3.30 \\
\hline \multicolumn{2}{|l|}{ Desired level } & $88-90$ & $17.5-18.0$ & & & $3.5-4.0$ & $2900-3000$ & $165: 1$ \\
\hline
\end{tabular}


mended level (2700-2800 kcal/kg). The CP (Avr-18.74\%) of layer grower ration was higher than the recommended level (16.517.0\%). The layer layer feed samples F03-01 and F03-03 were found to contain lower level of ME (2604 and $2512 \mathrm{kcal} / \mathrm{kg}$ ). In most cases, the nutrient contents and energy values of the feed samples collected from the farm F05 were in compliance with the desired level. However, layer layer feed F0506 and F05-07 were found to contain alarmingly high amount of Ca (6.52 and 6.42\%). The farm F09 had procured their layer feed from local retailer shop and a wide variation was observed in the different nutrient contents. The most remarkable fluctuation was noticed in $\mathrm{ME}$ and ash content of layer layer feed sample, which varied from 2469 to $2980 \mathrm{kcal} / \mathrm{kg}$ and 8.86 to $14.04 \%$ respectively.

In general the quality of the feed used in the breeder farms (F04, F08 and F11) appeared to be better than those of broiler and layerfarms. Breeder feeds were found to contain nutrient contents as per recommendation of the strain producing company. However, feed sample F04-03 and F04-04 of farm-4 contained excessive calcium (2.53\%), though the recommended levels were $1.0 \%$.

In general the quality of the feed used in the breeder farms (F04, F08 and F11) appeared to be better than those of broiler and layer farms. Breeder feeds were found to contain

Table VIII. Aflatoxin content (ppb) of poultry feeds collected from different farms round the year

\begin{tabular}{l|c|c|c|c|c|c|c|c|c|c|c|r|r}
\hline \multicolumn{10}{c}{ Farm } \\
\hline Months & F01 & F02 & F03 & F04 & F05 & F06 & F07 & F08 & F109 & F10 & F011 & F012 & of Farms \\
Dec & 0 & 0 & 0 & 0 & 0 & 0 & 0 & 0 & 0 & 0 & 0 & 0 & 0 \\
Jan & 0 & 0 & 0 & 0 & 0 & 0 & 0 & 0 & 0 & 0 & 0 & 0 & 0 \\
Feb & 0 & 0 & 0 & 0 & 0 & 0 & 0 & 0 & 0 & 0 & 0 & 0 & 0 \\
Mar & 0 & 0 & 0 & 0 & 0 & 0 & 0 & 0 & 0 & 15 & 0 & 0 & 8 \\
Apr & 3 & 0 & 0 & 14 & 0 & 23 & 25 & 0 & 0 & 24 & 0 & 0 & 41 \\
May & 23 & 34 & 32 & 25 & 32 & 34 & 0 & 0 & 17 & 56 & 0 & 0 & 66 \\
Jun & 34 & 54 & 45 & 36 & 0 & 54 & 95 & 0 & 56 & 41 & 0 & 76 & 75 \\
Jul & 98 & 40 & 86 & 47 & 23 & 81 & 33 & 76 & 85 & 81 & 42 & 78 & 100 \\
Aug & 82 & 31 & 42 & 12 & 14 & 24 & 48 & 12 & 54 & 21 & 0 & 51 & 91 \\
Sep & 54 & 14 & 10 & 0 & 0 & 10 & 23 & 0 & 24 & 35 & 0 & 12 & 66 \\
Oct & 21 & 14 & 0 & 0 & 0 & 0 & 18 & 0 & 17 & 14 & 0 & 0 & 41 \\
Nov & 0 & 0 & 0 & 0 & 0 & 0 & 0 & 0 & 0 & 0 & 0 & 0 & 0 \\
\hline Avr & 26.25 & 15.58 & 17.92 & 11.17 & 5.75 & 18.83 & 20.17 & 7.33 & 21.08 & 23.92 & 3.5 & 18.08 & \\
\hline
\end{tabular}


nutrient contents as per recommendation of the strain producing company. However, feed sample F04-03 and F04-04 of farm-4 contained excessive calcium (2.53\%) though the recommended levels were $1.0 \%$.

In appeared from the table VIII that feed from most of the farms contained aflatoxin in the months of June, July and August. In feed samples only $B_{1}$ was detected though the samples were subjected to analysis for $B_{1}, B_{2}$ and $G_{2}$ Considering the number of farm effected, the percentage of incidence in those months were 75, 100 and 91\% respectively. In the month of September and October the rates of incidence declined gradually and were recorded as $66 \%$ and $41 \%$ respectively. From November till February.

\section{Conclusion}

On the basis of this study it can be concluded that different feeding systems are practiced in the farms of Bangladesh. The quality of feed used in the breeder farms appeared to be better than those of broiler and layer farms. The farms, which have their own laboratory facilities, are producing better quality, uniform and balanced feed. The feed produced by the renowned feed-mill are better than those from retailer shop.

\section{Reference}

Ahmed, S. and N. Islam. Backyard poultry development project in 100 villages. Proceeding of the 1st Conferences of Bangladesh Animal Husbandry Association. Bangladesh Agricultural Research Council, Dhaka, 23-24 February (1990), pp: 183, 1990.

AOAC. (1990) Official methods of Analysis, Association of Official Analytical Chemists, Washington D.C. 15th edition.

Coker, R.D, jewers,., K,I, Tomlins and Blunden, G. (1988) Prior to Aflatoxin Assay by HPLTC. Chromatographia, 25:875.

Hall and Haczkaylo. (1963) Folin -Wu- Method for determination of glucose In Methods and procedures for plant Biochemical research. Publisher: The exchange stores, College Station, Texas.

Kent-Jones, D.W. and A.J. Amons. (1967) Modern cereal chemistry. London Food Trade press Ltd. 7 Garrick street, W.C, 2, 6th edition, pp: 558-563.

Leclercq, B., Y. Henry, and J.M. Perez. (1987) Energy value of Feeds for Non-ruminants. In: Feeding of Non-ruminant Livestock. (Translated and edited by Julian Wiseman). Butterworth and Co. (publisher) Ltd, London,10. 
Page, A.L., R.H. Miller. and D.R. Keeney. (1982) Methods of Soil Analysis, Part-2, Amer. Soc. Agron., Inc. Soil So. Soc. Amer., Inc. Madison, Wiscansin, USA, pp: 152-531.

Romer, T.R. (1980) A method for determination of aflatoxin from food grain Analysis, 3rd edition, 59:110-117.
Shil, R.N. and Debnath S.C. (2001) An Introduction to the Theory of Statistics, 3rd revise edition, pp: 47.

Received : September, 26, 2006;

Accepted : August, 22, 2007 